\title{
EVALUATION OF THE EFFICACY OF THE ASSOCIATION OF URAPIDIL WITH OTHER ANTIHYPERTENSIVE DRUGS IN THE PREHOSPITAL EMERGENCY IN ROMANIA
}

\author{
GABRIELA PRODAN (PURA) ${ }^{1,2 \#}$, CRISTINA NASTASA ${ }^{1 *}$, GABRIEL MARC $^{1 \#}$, HORIA SIMU $^{2}$, \\ OVIDIU ONIGA $^{1}$
}

I "Iuliu Hațieganu” University of Medicine and Pharmacy, Department of Pharmaceutical Chemistry, 41 Victor Babeș Street, 400012, Cluj-Napoca, Romania

${ }^{2}$ Department of Ambulance Emergency Service, 55 Horea Street, 400202, Cluj-Napoca, Romania

*corresponding author: cmoldovan@umfcluj.ro

${ }^{\#}$ Authors with equal contribution

Manuscript received: January 2019

\begin{abstract}
The aim of this study was to evaluate the efficacy of the association of some antihypertensive drugs in the pre-hospital emergency, in Romania. There were used inhibitors of the converting enzyme (captopril, enalapril), a loop diuretic (furosemide) and an $\alpha_{1}$-adrenergic receptors blocker (urapidil), from the toolkit of the Ambulance Emergency Service of Cluj county, Romania. These drugs were administered, considering the age of the patient, the duration and the severity of the arterial hypertension. The decrease of the blood pressure was significant in the case of the urapidil used in monotherapy, while the co-administration with captopril or enalapril did not bring an important contribution in terms of efficacy. The use of urapidil alone was also very favourable due to the reduction of the time intervention and also, to its cost-effectiveness.
\end{abstract}

\section{Rezumat}

Scopul acestui studiu a fost evaluarea eficacităţii asocierii unor medicamente antihipertensive în urgența prespitalicească, în România. Au fost utilizați inhibitori ai enzimei de conversie (captopril, enalapril), un diuretic de ansă (furosemid) și un blocant al receptorilor $\alpha_{1}$-adrenergici (urapidil), din trusa Serviciului de Ambulanță din județul Cluj. Aceste medicamente au fost administrate ținând cont de vârsta pacientului, durata și severitatea hipertensiunii arteriale. Scăderea tensiunii arteriale a fost semnificativă în cazul utilizării urapidilului în monoterapie, în timp ce asocierea cu captopril sau enalapril nu a adus un aport important ca eficacitate. Utilizarea urapidilului singur poate fi considerată favorabilă și datorită reducerii timpului și a costurilor de intervenție.

Keywords: urapidil, antihypertensive, prehospital emergency, coadministration

\section{Introduction}

High blood pressure represents a problem for the worldwide population, especially for the elderly one. It is a major cardiovascular risk factor, sending the patients frequently to primary care or the hospital emergency departments. This may be corrected and kept under control by the regular controls at the general medical doctor, the cardiologist and by the adequate medication. Because of the lifestyle of patients (the lack of sport activities, of quality nutrients, the excessive consume of caffeine products, lack of sleep), their genetic inheritance, their comorbidities or comedication, the high blood pressure may threat the life of a person by causing hypertensive crises, which require the emergency intervention.

The hypertensive crisis is defined as acute blood pressure elevations that can cause functional or structural alterations in hypertension target organs (heart, brain, kidney, retina, arteries) [1]. Hypertensive crisis can be further classified as a hypertensive urgency or hypertensive emergency, depending on the presence or absence of an organ damage. Hypertensive urgency is defined as a systolic blood pressure (SBP) higher than $180 \mathrm{mmHg}$ or a diastolic blood pressure (DBP) higher than $120 \mathrm{mmHg}$ in the absence of, or minimal, target organ damage [2]. Hypertensive emergency is consistently seen with a value of DBP higher than $120 \mathrm{mmHg}$, which irrevocably causes organ damage including, but not limited to, the cardiac, renal, and central nervous systems [3]. It represents $25-30 \%$ of all hypertensive crises. The absolute blood pressure (BP) elevation is not a necessary criterion for the diagnosis of hypertensive emergency, as long as there is evidence of acute organ damage. There were identified several risk factors significantly associated with hypertensive crises: female sex, higher grade of obesity, the presence of hypertensive heart disease, a big number of antihypertensive drugs, the nonadherence to medication, the suboptimal treatment of hypertension [4], the lack of a primary care physician and medical insurance, lack of resources, smoking, 
diabetes, autumn season, and the morning hours between $6 \mathrm{AM}$ and 12 noon [5].

The management of the hypertensive crises is a challenge for the medical professionals because of the gravity and the emergency character of this affection. The initial evaluation of a patient with an acute increase in BP should investigate the alcohol consumption, some food ingestion (cheese with high tyramine content), the use of illicit substances (cocaine) and concomitant drug treatment with corticosteroids and mineralocorticoids, oestrogens, cyclosporine, carbamazepine, NSAID or metoclopramide. The optimal screening includes repeated measurements of BP, laboratory examinations (urine-analysis, electrolytes, creatinine, urea, and a full blood count), an electro-cardiogram and fundoscopy [6].

The choice of the best $\operatorname{drug}(\mathrm{s})$ with the best benefitrisk ratio depends on the correct recognition of the clinical picture and the consideration of comorbidities. The drugs usually used in the management of the hypertensive crisis are: calcium channel blockers, $\beta$-blockers, angiotensin-converting enzyme inhibitors, loop diuretics, calcium receptor antagonists, angiotensinconverting enzyme inhibitors, arterial and venous vasodilators and drugs with other mechanisms of action (ex. urapidil) [7]. Urapidil, an $\alpha$-blocker with additional actions in the central nervous system (stimulates serotonin 5- $\mathrm{HT}_{1 \mathrm{~A}}$ receptors) has been found effective, since it induces vasodilatation without tachycardia [8-10] and the BP reduction is generally not associated with an increase in intracranial pressure and impairment of cerebral perfusion pressure [11]. Plus, urapidil improves the coronary flow, myocardial perfusion and the ventricular function, by limiting the infarct size [12].

Urapidil is considered a safe and effective vasodilator for the elderly patients with acute left heart failure, providing additional benefits in renal insufficiency and metabolic disorders due to its neutral or even positive effect on renal blood perfusion, blood lipid and blood glucose metabolism [13, 14].

Prompted by all these aspects and by our interest in this domain [15], we present in this article the evaluation of the efficacy of urapidil used alone, in one or multiple doses, with urapidil in association with captopril, enalapril or furosemide (when these 3 drugs failed), in the hypertensive crises managed by the C-2 ambulance emergency medical teams from Cluj county, Romania.

\section{Materials and Methods}

This retrospective study was conducted from October 2017 until May 2018 and has included the hypertensive emergencies requested at the emergency dedicated phone number 112, for the medical C2type teams. The study included 169 patients (male and female), aged from 34 to 90 years old, suffering from arterial hypertension crisis.

This paper presents the results of the retrospective study which evaluated the efficacy of the association of captopril $25 \mathrm{mg}$ sublingual (sl)/enalapril $1.25 \mathrm{mg}$ intravenous/furosemide $20 \mathrm{mg}$ intravenous (iv) and urapidil $12.5 \mathrm{mg}$ intravenous (iv), in the prehospital emergency intervention.

The patients were separated in four groups, based on the administered drugs (captopril, enalapril, furosemide and urapidil) during the intervention of the medical teams. The first group received urapidil alone (U1), the others captopril + urapidil $(\mathrm{C}+\mathrm{U})$, enalapril + urapidil $(\mathrm{E}+\mathrm{U})$ or furosemide + urapidil $(\mathrm{F}+\mathrm{U})$, due to the lack of effect of the first antihypertensive drug administered.

The hypertensive crisis was defined as systolic blood pressure $(\mathrm{SBP})>180 \mathrm{mmHg}$ and the diastolic blood pression $(\mathrm{DBP})>120 \mathrm{mmHg}$, according to the therapeutic guides [16]. Mean blood pressure (MBP) was calculated using the formula: $\mathrm{MBP}=(2 \mathrm{x} \mathrm{DBP}+$ $\mathrm{SBP}) / 3$. The blood pressure was measured by the sphygmomanometers from the ambulance C2-type cars. The two tailed $\mathrm{p}$ values were computed using a 0.05 level of significance. All values were statistically interpreted with the help of $\mathrm{R}$ environment for statistical computing, version 3.2.3 [17].

This study did not include the intubated patients, the ones with renal diseases, the pregnant or breastfeeding women.

\section{Results and Discussion}

Evaluation of the urapidil's effect in the hypertensive crisis, used alone

A first objective of our study was to investigate the effect of the administration of urapidil alone, on the values of the blood pressure, for the patients who asked for the emergency ambulance service for a hypertensive crisis. All data regarding the SBP, DBP, MBP on arrival and after the administration of 1 to 4 doses of urapidil, are presented in Table I, as median values.

The median age of the patients was in the 63.5 - 69 years old interval. On arrival, the median values for SBP were 183 - $223 \mathrm{mmHg}$, for DBP $104-126$ $\mathrm{mmHg}$ and for MBP, 131.33 - $157 \mathrm{mmHg}$. The intervention time varied from 40 to 58.50 minutes. In the U1group the patients received 1 to 4 doses of $12.5 \mathrm{mg}$ iv, a significant reduction of the arterial blood pressure was registered, the patients coming out of the hypertensive crisis in the first 10 minutes after the drug administration. 
The reduction of SBP, DBP and MBP after the administration of urapidil alone

\begin{tabular}{|c|c|c|c|c|c|c|}
\hline \multirow{2}{*}{\multicolumn{2}{|c|}{ Parameter }} & \multicolumn{5}{|c|}{ Number of received doses of urapidil } \\
\hline & & 1 & 2 & 3 & 4 & 1- 4 doses \\
\hline \multicolumn{2}{|c|}{ Number of patients } & 12 & 65 & 10 & 16 & 103 \\
\hline \multicolumn{2}{|c|}{ Intervention time (min) } & $\begin{array}{c}44.50 \\
(30.75-50.00)\end{array}$ & $\begin{array}{c}40.00 \\
(27.00-50.00)\end{array}$ & $\begin{array}{c}54.50 \\
(39.00-63.00)\end{array}$ & $\begin{array}{c}58.50 \\
(50.00-69.00)\end{array}$ & $\begin{array}{c}45.00 \\
(30.00-54.00)\end{array}$ \\
\hline \multirow{3}{*}{$\underset{(\mathrm{mmHg})}{\mathrm{SBP}}$} & on arrival & $\begin{array}{c}183.00 \\
(179.50-187.00)\end{array}$ & $\begin{array}{c}200.00 \\
(190.00-211.00)\end{array}$ & $\begin{array}{c}223.00 \\
(215.50-234.75)\end{array}$ & $\begin{array}{c}206.50 \\
(193.75-210.25)\end{array}$ & $\begin{array}{c}200.00 \\
(190.00-212.50)\end{array}$ \\
\hline & reduction & $\begin{array}{c}25.50 \\
(19.75-30.00)\end{array}$ & $\begin{array}{c}41.00 \\
(30.00-59.00)\end{array}$ & $\begin{array}{c}59.00 \\
(51.00-78.25)\end{array}$ & $\begin{array}{c}58.00 \\
(54.50-69.00)\end{array}$ & $\begin{array}{c}44.00 \\
(30.00-59.00)\end{array}$ \\
\hline & $\%$ reduction & $\begin{array}{c}13.88 \\
(11.02-16.70)\end{array}$ & $\begin{array}{c}21.99 \\
(14.68-27.01)\end{array}$ & $\begin{array}{c}27.57 \\
(23.89-34.18)\end{array}$ & $\begin{array}{c}30.15 \\
(26.40-32.79)\end{array}$ & $\begin{array}{c}22.93 \\
(15.43-29.61)\end{array}$ \\
\hline \multirow{3}{*}{$\begin{array}{c}\text { DBP } \\
(\mathbf{m m H g})\end{array}$} & on arrival & $\begin{array}{c}104.00 \\
(87.00-115.00) \\
\end{array}$ & $\begin{array}{c}111.00 \\
(101.00-120.00) \\
\end{array}$ & $\begin{array}{c}126.00 \\
(115.25-137.75) \\
\end{array}$ & $\begin{array}{c}111.50 \\
(103.75-121.75) \\
\end{array}$ & $\begin{array}{c}111.00 \\
(100.50-122.50) \\
\end{array}$ \\
\hline & reduction & $\begin{array}{c}13.00 \\
(9.50-17.50)\end{array}$ & $\begin{array}{c}20.00 \\
(13.00-31.00)\end{array}$ & $\begin{array}{c}27.50 \\
(27.00-44.75) \\
\end{array}$ & $\begin{array}{c}23.00 \\
(15.75-39.50) \\
\end{array}$ & $\begin{array}{c}23.00 \\
(13.50-31.50)\end{array}$ \\
\hline & $\%$ reduction & $\begin{array}{c}12.28 \\
(8.70-16.92) \\
\end{array}$ & $\begin{array}{c}19.05 \\
(13.27-28.00) \\
\end{array}$ & $\begin{array}{c}24.53 \\
(21.54-29.50) \\
\end{array}$ & $\begin{array}{c}22.03 \\
(14.39-33.21) \\
\end{array}$ & $\begin{array}{c}20.72 \\
(13.53-28.00) \\
\end{array}$ \\
\hline \multirow{3}{*}{$\begin{array}{c}\text { MBP } \\
(\mathbf{m m H g})\end{array}$} & on arrival & $\begin{array}{c}131.33 \\
(117.67-138.50) \\
\end{array}$ & $\begin{array}{c}140.33 \\
(131.33-150.33)\end{array}$ & $\begin{array}{c}157.00 \\
(155.33-166.33) \\
\end{array}$ & $\begin{array}{c}140.17 \\
(136.08-150.67\end{array}$ & $\begin{array}{c}140.00 \\
(131.83-152.00)\end{array}$ \\
\hline & reduction & $\begin{array}{c}15.83 \\
(14.33-23.33) \\
\end{array}$ & $\begin{array}{c}29.00 \\
(20.00-38.00) \\
\end{array}$ & $\begin{array}{c}43.17 \\
(37.67-48.83) \\
\end{array}$ & $\begin{array}{c}35.50 \\
(28.08-46.67) \\
\end{array}$ & $\begin{array}{c}30.00 \\
(21.33-38.83) \\
\end{array}$ \\
\hline & $\%$ reduction & $\begin{array}{c}12.65 \\
(10.31-18.70)\end{array}$ & $\begin{array}{c}20.89 \\
(14.81-26.26)\end{array}$ & $\begin{array}{c}24.70 \\
(24.30-30.27)\end{array}$ & $\begin{array}{c}25.47 \\
(20.24-30.97)\end{array}$ & $\begin{array}{c}21.62 \\
(15.70-26.31)\end{array}$ \\
\hline \multicolumn{2}{|c|}{ Age (years) } & $\begin{array}{c}69.00 \\
(57.75-76.25)\end{array}$ & $\begin{array}{c}67.00 \\
(60.00-76.00)\end{array}$ & $\begin{array}{c}65.50 \\
(60.00-74.75)\end{array}$ & $\begin{array}{c}63.50 \\
(59.00-78.50)\end{array}$ & $\begin{array}{c}67.00 \\
(59.00-76.50)\end{array}$ \\
\hline
\end{tabular}

It can be observed that the major reduction was that of SBP, the persistence of HTA dropping by $21.99 \%$ after the second dose, after the third, by $27.57 \%$ and after the fourth, by $30.15 \%$ (Figure 1). The reduction of the blood pressure was gradually augmented by the repetitive injection of urapidil.

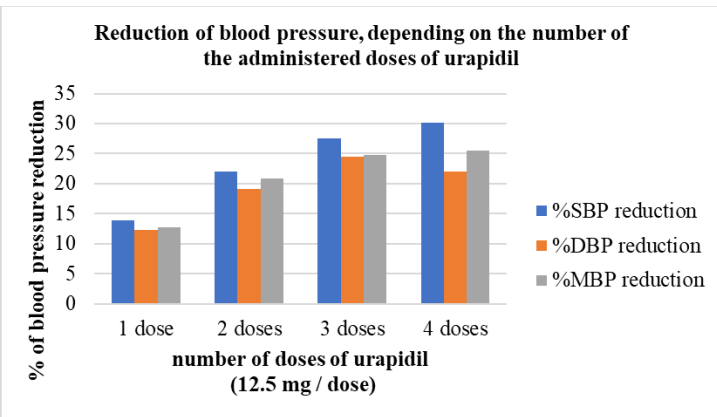

Figure 1.

The reduction of blood pressure, depending on the number of the doses of urapidil (U1 group)

Evaluation of the urapidil's effect in the hypertensive crisis, in association with other antihypertensive drugs The second objective of our study was to evaluate the efficacy of the association of $12.5 \mathrm{mg}$ of urapidil (iv) with other antihypertensive drugs used in the hypertensive crisis by the emergency service in Romania, such as: captopril $25 \mathrm{mg}$ (sl), enalapril 25 $\mathrm{mg}$ (iv) or furosemide $20 \mathrm{mg}$ (iv). The results are depicted in Table II. It can be observed that the reduction of the blood pressure was not significant after the association with captopril. Also, the time duration until the apparition of the antihypertensive effect is elevated, therefore this association is not suggested as an efficient one in the emergency hypertensive crisis. An explanation of this may be the reduced bioavailability after the sublingual administration. The use of enalapril determines a decrease of blood pressure, by a cumulative effect. The guides used in the emergency precise that it may pass about $4 \mathrm{~h}$ until the effect of enalapril installs [18, 19], time needed for the bioactivation of enalapril into the active metabolite enalaprilat. This period depass the time for the intervention of the ambulance. The decrease of the blood pressure high values may be detected after the patient is already in the emergency hospital or the C-2 ambulance medical team has already left the patient, at home.

Instead, the co-administration of furosemide $20 \mathrm{mg}$ (iv) resulted in a decrease of SBP with $28.21 \%$, of DBP with $31.47 \%$ and of the MBP with $31.70 \%$, higher than for the other two drugs, $\mathrm{C}+\mathrm{U}$ or $\mathrm{E}+\mathrm{U}$. The intervention time at the administration of captopril was close to that registered in the case of the coadministration urapidil-furosemide. Thus, the use of urapidil in monotherapy reduces the time and plus, the cost of the intervention. Considering these aspects, the administration of this drug is favourable for the life of the patient in hypertensive crisis, for the medical teams which are able to respond and solve more cases due to the time efficiency and also for the financial department, being more cost-effective. 
Table II

The reduction of SBP, DBP and MBP after the administration of urapidil in association with other

\begin{tabular}{|c|c|c|c|c|c|c|c|c|c|c|}
\hline \multirow{2}{*}{ 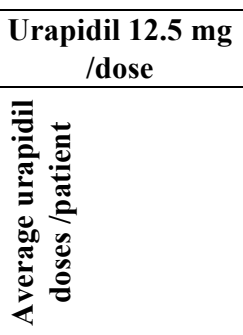 } & \multicolumn{2}{|c|}{ Associated drug } & \multirow[b]{2}{*}{ 莺 } & \multirow{2}{*}{ 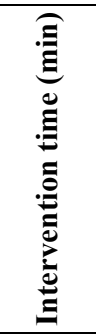 } & \multicolumn{2}{|c|}{$\begin{array}{c}\text { SBP } \\
\text { reduction }\end{array}$} & \multicolumn{2}{|c|}{$\begin{array}{c}\mathrm{DBP} \\
\text { reduction }\end{array}$} & \multicolumn{2}{|c|}{$\begin{array}{c}\text { MBP } \\
\text { reduction }\end{array}$} \\
\hline & 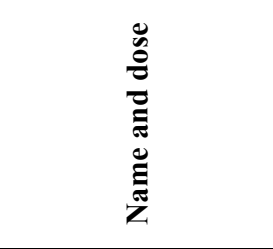 & 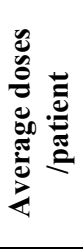 & & & 些 & $\partial^{0}$ & $\stackrel{000}{\stackrel{000}{E}}$ & $0^{\circ}$ & & $\partial^{0}$ \\
\hline 2.18 & captopril $25 \mathrm{mg}(\mathrm{sl})$ & 1.14 & 22 & 49.00 & 41.81 & 20.37 & 24.31 & 20.68 & 29.00 & 20.98 \\
\hline 1.71 & $\begin{array}{c}\text { enalapril } \\
1.25 \mathrm{mg} \text { (iv) }\end{array}$ & 1.42 & 28 & 51.11 & 44.03 & 20.93 & 16.28 & 14.92 & 24.67 & 18.10 \\
\hline 1.81 & $\begin{array}{l}\text { furosemide } 20 \mathrm{mg} \\
\text { (iv) }\end{array}$ & 1.50 & 16 & 54.94 & 61.25 & 28.21 & 42.25 & 31.47 & 50.00 & 31.70 \\
\hline
\end{tabular}

We intended to analyse, in detail, if the association of other antihypertensive drugs brings a real benefit to the decrease of blood pressure, compared to the use of urapidil alone, in 1 to 4 doses. The data obtained are presented in Table III.

Table III

The effect of the co-administration of other antihypertensive drugs, compared to the use of urapidil alone, in the approach of the hypertensive crisis

\begin{tabular}{|c|c|c|c|c|}
\hline \multicolumn{2}{|c|}{ Effect of urapidil on SBP (\%) } & \multicolumn{2}{|c|}{ Effect of urapidil + associated drug on SBP (\%) } & \multirow{2}{*}{$\begin{array}{c}\mathbf{p} \\
0.280\end{array}$} \\
\hline 2.18 doses & 21.77 & 2.18 doses urapidil +1.14 doses captopril & 20.37 & \\
\hline 1.71 doses & 19.19 & 1.71 doses urapidil +1.42 doses enalapril & 20.93 & 0.267 \\
\hline 1.81 doses & 19.74 & 1.81 doses urapidil +1.5 doses furosemide & 28.21 & 0.048 \\
\hline \multicolumn{2}{|c|}{ Effect of urapidil on DBP (\%) } & \multicolumn{2}{|c|}{ Effect of urapidil + associated drug on DBP (\%) } & p \\
\hline 2.18 doses & 18.36 & 2.18 doses urapidil +1.14 doses captopril & 20.68 & 0.976 \\
\hline 1.7 & 16.72 & $1.71 \mathrm{c}$ & 14.92 & 0.022 \\
\hline 1.81 doses & 17.07 & 1.81 doses urapidil +1.5 doses furosemide & 31.47 & 0.001 \\
\hline \multicolumn{2}{|c|}{ Effect of urapidil on MBP (\%) } & \multicolumn{2}{|c|}{ Effect of urapidil + associated drug on MBP (\%) } & p \\
\hline 2.18 doses & 19.57 & 2.18 doses urapidil +1.14 doses captopril & 20.98 & 0.569 \\
\hline 1.71 doses & 17.58 & 1.71 doses urapidil +1.42 doses enalapril & 18.10 & 0.051 \\
\hline 1.81 doses & 18.01 & 1.81 doses urapidil +1.5 doses furosemide & 31.70 & 0.004 \\
\hline
\end{tabular}

The association with captopril resulted in a decrease of SBP reduction, from $21.77 \%$ for the urapidil alone, to $20.37 \%$ in association. The administration of enalapril proved to be beneficial, the reduction of SBP being 20.93\% for the association, while for urapidil alone, the value was $19.19 \%$. Still, the contribution of enalapril is not significant and this coadministration is not suggested for the intervention in the hypertensive crisis. The most efficient proved to be the co-administration of furosemide, in this case, the reduction of SBP being of $28.21 \%$, instead of only $19.74 \%$ for the urapidil alone.

For the values registered for DBP, the association of captopril resulted in a reduction of $20.68 \%$ of the parameter, while for urapidil alone this was $18.36 \%$. The co-administration of enalapril didn't have a favourable impact, since the reduction was $14.92 \%$ and for urapidil alone, $16.72 \%$. Still, the most important effect was obtained after the association of furosemide, with a reduction of $31.47 \%$, compared to $17.07 \%$.

The values for MBP are in total agreement with those obtained for SBP and DBP.

\section{Conclusions}

The results of our study showed that urapidil intravenous is an efficient drug in reducing the values of SBP and DBP in the hypertensive crisis, even used alone, in 1 to 4 doses. The association of other antihypertensive drugs from the emergency service kit in Cluj County, Romania, such as captopril sublingual or enalapril intravenous did not bring an important contribution to the decrease of the blood pressure, prolonging the intervention time and the costs. Instead, the co-use of furosemide intravenous proved to be useful, in association with urapidil, the percentage of the reduction of blood pressure parameters being more pronounced than for urapidil used alone, in monotherapy.

\section{Conflict of interest}

The authors declare no conflict of interest. 


\section{References}

1. Albaladejo Blancoa C, Sobrino Martínez J, Vázquez González S, Crisis hipertensivas: seudocrisis, urgencias y emergencias. Hipertens Riesgo Vasc., 2014; 31(4): 132-142.

2. Gifford RW Jr, Management of hypertensive crises. JAMA, 1991; 266(6): 829-835.

3. Cherney D, Straus S, Management of patients with hypertensive urgencies and emergencies: a systematic review of the literature. J Gen Intern Med., 2002; 17(12): 937-945.

4. Tisdale JE, Huang MB, Borzak S, Risk factors for hypertensive crisis: importance of out-patient blood pressure control. Fam Pract., 2004; 21(4): 420-424.

5. Wang Y, Wang QJ, The prevalence of prehypertension and hypertension among US adults according to the new joint national committee guidelines: new challenges of the old problem. Arch Intern Med., 2004; 164(19): 2126-2134.

6. Katz JN, Gore JM, Amin A, Anderson FA, Dasta JF, Ferguson JJ, Kleinschmidt K, Mayer SA, Multz AS, Peacock WF, Peterson E, Pollack C, Sung GY, Shorr A, Varon J, Wyman A, Emery LA, Granger $\mathrm{CB}$, Practice patterns, outcomes, and end-organ dysfunction for patients with acute severe hypertension: the Studying the Treatment of Acute hyperTension (STAT) Registry. Am Heart J., 2009; 158(4): 599-606.

7. Arbe G, Pastor I, Franco J, Diagnostic and therapeutic approach to the hypertensive crisis. Med Clin., 2018; 150(8): 317-322.

8. Rosei EA, Salvetti M, Treatment of hypertensive urgencies and emergencies. European Society of Hypertension Scientific Newsletter: Update on Hypertension Management, 2006; 7(28): 1-2.

9. Alijotas-Reig J, Bove-Farre I, de Cabo-Frances F, Angles-Coll R, Effectiveness and safety of prehospital urapidil for hypertensive emergencies. Am J Emerg Med., 2001; 9(2): 130-133.

10. Buch J, Urapidil, a dual-acting antihypertensive agent: Current usage considerations. Adv Ther., 2010; 27(426): 426-443.
11. Salvetti M, Paini A, Bertacchini F, Stassaldi D, Aggiusti C, Agabiti C, Maria R, Muiesan L, Acute blood pressure elevation: Therapeutic approach. Pharmacol Res., 2018; 130: 180-190.

12. Yao DK, Jia SQ, Wang L, Li HW, Zhang YC, Wang YL, Wang LX, Therapeutic effect of urapidil on myocardial perfusion in patients with STelevation acute coronary syndrome. Eur J Int Med., 2009; 20: 152-157.

13. He J, Wang J, Zhou Y, Fu Y, Qin J, Qin S, Chen X, Guo J, Wang D, Zhan H, Guan W, Xu Y, Hua Q, Safety and efficacy of urapidil and nitroglycerin in the treatment of elderly patients with acute heart failure: a randomized multi-center parallel-control study in China. Int J Clin Exp Med., 2017; 10(6): 9729-9739.

14. Yang W, Zhou YJ, Fu Y, Qin J, Qin S, Chen XM, Guo JC, Hua Q, A multicenter, randomized, trial comparing urapidil and nitroglycerin in multifactor heart failure in the elderly. Am J Med Sci., 2015; 350(2): 109-115.

15. Prodan (Pura) G, Leucuța DC, Marc G, Simu H, Nastasă C, Oniga $\mathrm{O}$, The impact of urapidil use in hypertension prehospital emergency intervention. Farmacia, 2017; 65(6): 896-899.

16. Mallidi J, Penumetsa S, Lotfi A, Management of hypertensive emergencies. J Hypertens., 2013; 2: 1-6.

17. R. Core Team. R: A Language and Environment for Statistical Computing Vienna, Austria; 2016, www.r-project.org.

18. Malachias MVB, Barbosa ECD, Martim JFV, Rosito GBA, Toledo JY, Passarelli Jr O, $7^{\text {th }}$ Brazilian guideline of arterial hypertension: Chapter 14 Hypertensive Crisis. Arq Bras Cardiol., 2016; 107 (Suppl3): 79-83.

19. Migneco A, Ojetti V, De Lorenzo A, Gentiloni Silveri N, Savi L, Hypertensive crises: diagnosis and management in the emergency room. Eur Rev Med Pharmacol Sci., 2004; 8: 143-152. 